\title{
Direct qPCR is a sensitive approach to detect Mycoplasma contamination in U937 cell cultures
}

\author{
Zain Baaity ${ }^{1}$, Sven Breunig ${ }^{2}$, Kamil Önder ${ }^{2}$ and Ferenc Somogyvári ${ }^{* *}$ (i)
}

\begin{abstract}
Objective: We aim to directly detect Mycoplasma DNA in a U937 suspension cell culture without using DNA purification. In order to make Mycoplasma contamination monitoring easier, we optimized a commercially available quantitative PCR (qPCR)-based detection kit. We compared the sensitivity of direct qPCR against qPCR with a purified DNA template.

Results: Our findings indicate that qPCR worked optimally with a $6 \mu \mathrm{l}$ sample volume and a $52^{\circ} \mathrm{C}$ annealing-extension temperature. We were able to decrease the annealing-extension step time from 60 to $20 \mathrm{~s}$ without any major decrease in reaction sensitivity. The total cycle time of optimized direct qPCR was $65 \mathrm{~min}$. The optimized qPCR protocol was used to detect Mycoplasma DNA before and after DNA purification. Our findings indicate that direct qPCR had a higher sensitivity than regular qPCR. Ct levels produced by direct qPCR with $6 \mu \mathrm{l}$ templates were almost identical to $C t$ levels produced by regular qPCR with DNA purified from a $60 \mu \mathrm{l}$ cell culture sample (23.42 vs 23.49 average $C t$ levels, respectively). The optimized direct qPCR protocol was successfully applied to monitor the elimination of Mycoplasma contamination from U937 cell cultures.
\end{abstract}

Keywords: Mycoplasma, aPCR, PCR, Direct, Elimination

\section{Introduction}

Mycoplasma is a small cell-wall free prokaryotic bacterium with a remarkable diversity at the species level. Besides causing human respiratory and urogenital tract infections, Mycoplasma contamination of cell cultures is a frequent phenomenon. According to the DSMZGerman Collection of Microorganisms and Cell Cultures survey, the prevalence of Mycoplasma contamination of cell lines was $28 \%$ including Mycoplasma species $M$. orale, M. hyorhinis, M. arginini, M. fermentans, M. hominis and Acholeplasma laidlawii [1]. Mycoplasma contamination may be introduced by cross-infection with a Mycoplasma positive cell line, laboratory personnel (e.g. M. orale) or by contaminated cell-culture reagents such as fetal bovine serum. Indeed, bovine Mycoplasma species $M$. arginini and A. laidlawii are frequent contaminating agents. Mycoplasma contamination is hard to

\footnotetext{
*Correspondence: somogyvari.ferenc@med.u-szeged.hu

1 Department of Medical Microbiology and Immunobiology, Faculty of Medicine, University of Szeged, Dóm sq. 10., Szeged 6720, Hungary Full list of author information is available at the end of the article
}

prevent/eradicate since the bacterium is less sensitive to antibiotics commonly applied in cell cultures. Its small size $(0.3-1 \mu \mathrm{m})$ and non-rigid cell wall makes it also hard to remove by filtration. Mycoplasma infection has a pleiotropic effect on cellular physiology including altered metabolism, DNA, RNA and protein synthesis and proand anti-inflammatory effects [1-3]. U937 human monocytic cells, the cell-type used in this study, respond to the Mycoplasma infection by producing monocyte chemotactic protein-1, matrix metalloproteinase-12 [4] and interleukin-1 $\beta$ [5].

The high probability of introducing novel Mycoplasma infections into cell cultures means it is necessary to monitor cell culture ingredients and cell lines for $\mathrm{Myco}$ plasma contamination. There are a wide variety of detection methods available including metabolism detection and Mycoplasma genome detection by PCR and qPCR. Regular PCR has high sensitivity and specificity, but in the majority of cases requires nucleic acid purification and gel electrophoresis. qPCR eliminates the gel electrophoresis step, but regular qPCR protocols also include 
nucleic acid purification. DNA purification can be a long and laborious procedure, especially if there are several samples to be purified. Direct PCR and direct qPCR eliminate the purification step, significantly shortening the protocol, but the inhibitory effect of the direct sample can be present. Previously, direct qPCR methods have been successfully applied to monitor Chlamydia and herpes simplex virus- 2 growth and the antimicrobial effects of various compounds [6-11]. In this study, we want to leave out the DNA purification step and develop a direct qPCR detection method that is suitable to detect Mycoplasma contamination within U937 cell cultures.

\section{Main text \\ Materials and methods \\ Cell culture}

Mycoplasma infected U937 human monocytic cells were grown in an RPMI 1640 medium containing 10\% heatinactivated FBS (Sigma, St. Louis, MO, USA), and $50 \mu \mathrm{g} /$ $\mathrm{mL}$ gentamicin at $37{ }^{\circ} \mathrm{C}$ in $5 \% \mathrm{CO}_{2}$, all within a $25 \mathrm{~cm}^{2}$ cell culture flask (Greiner Bio-One Hungary, Mosonmagyaróvár, Hungary).

\section{Mycoplasma elimination}

Mycoplasma elimination was performed using Mycoplasma Elimination Reagent (Bio-Rad, Hercules, CA, USA). The reagent was added to the RPMI 1640 medium at a $0.5 \mu \mathrm{g} / \mathrm{ml}$ final concentration and the U937 cells were then cultured in this medium for 7 days.

\section{DNA extraction and $q P C R$}

DNA was extracted from Mycoplasma infected U937 cell supernatants using the Qiagen QIAamp DNA Mini Kit (Qiagen, Hilden, Germany) according to the manufacturer's instructions. PhoenixDx ${ }^{\circledR}$ Mycoplasma Mix (Procomcure Biotech, Thalgau, Austria) was used in the qPCR experiments. qPCRs with $20 \mu \mathrm{l}$ final volume were performed using the Bio-Rad CFX Connect qPCR realtime system. A statistical comparison of qPCR cycle threshold $(\mathrm{Ct})$ values was performed with Student's $t$ test, as described previously [12].

\section{Results}

To achieve optimal sensitivity and the shortest possible reaction time of direct $\mathrm{qPCR}$, we followed a step-wise optimization of the PhoenixDx Mycoplasma Mix (Procomcure Biotech, Thalgau, Austria) protocol that was originally designed to amplify purified DNA samples. First, we tested the optimal annealing/extension temperature for detecting unpurified Mycoplasma DNA in Mycoplasma-infected U937 cell culture supernatants (Fig. 1a). The results indicated that reactions with 50-52 ${ }^{\circ} \mathrm{C}$ annealing/extension temperature produced the lowest $\mathrm{Ct}$ values $(26.84 \pm 0.14-27.06 \pm 0.26)$. We chose the $52{ }^{\circ} \mathrm{C}$ annealing/extension temperature for further tests. Next, we tested to see whether reducing the annealing/extension time might influence qPCR performance (Fig. 1b). Our findings showed that the $60 \mathrm{~s}$ annealing/extension time provided the lowest $\mathrm{Ct}$ values $(23.56 \pm 0.47)$, but the 20 and $40 \mathrm{~s}$ annealing/ extension times led to only slightly higher $\mathrm{Ct}$ values $(24.20 \pm 0.23,24.11 \pm 0.27$, respectively), which suggested that reducing the annealing/extension time from 60 to $20 \mathrm{~s}$ had a minimal influence on qPCR sensitivity. $20 \mathrm{~s}$ annealing/extension time was used for further qPCRs. Next, we tested the effect of sample volume on qPCR performance (Fig. 1c). The Ct levels of samples with $6 \mu \mathrm{l}, 8 \mu \mathrm{l}$ and $10 \mu \mathrm{l}$ volumes of supernatants were similar (21.92-22.13 Ct value range), indicating that qPCR sensitivity is influenced by higher Mycoplasma DNA content and also by a higher level of qPCR inhibition in the 8 and $10 \mu \mathrm{l}$ samples. In further experiments, we opted for the $6 \mu \mathrm{l}$ sample volume. Finally, we compared the performance of direct $\mathrm{qPCR}$ and regular qPCR with purified DNA samples (Fig. 1d). The QIAamp DNA purification kit was used to isolate Mycoplasma DNA from U937 cell cultures (medium + cells). The elution volume was $100 \mu \mathrm{l}$. A comparison of the $6 \mu \mathrm{l}$ direct sample volume and $6 \mu \mathrm{l}$ purified sample was not possible as just $6 \mu \mathrm{l}$ of the $100 \mu \mathrm{l}$ total elution volume could be used during regular qPCR. Therefore we also decreased the $6 \mu$ ldirect sample volume by a factor of $6 / 100(0.36 \mu \mathrm{l})$. In a comparison of these samples we found that the $6 \mu$ purified sample produced lower Ct values $(\sim 2$ cycles $)$ than the $0.36 \mu$ lirect sample, suggesting a low level of qPCR inhibition of the supernatant. However, when we compared the $\mathrm{Ct}$ levels of samples with $6 \mu \mathrm{l}$ supernatant to the Ct levels of samples with purified DNAs we noticed that the $C t$ values produced with $6 \mu \mathrm{l}$ supernatants were almost identical to those of the purified $60 \mu \mathrm{l}$ supernatant $(23.42 \pm 0.26$, $23.49 \pm 0.30$, respectively) indicating an altogether higher sensitivity of the direct qPCR.

As an application of optimized direct qPCR we monitored Mycoplasma elimination from the infected U937 cell culture. Our results showed that the supernatants $(n=4)$ containing removal agent or free from removal agent both resulted in nearly the same $\mathrm{Ct}$ levels (27.04 \pm 0.24 and 26.94 \pm 0.45 , respectively) (Fig. 2a). This indicated that the presence of removal agent did not influence qPCR performance. Mycoplasma DNA dropped rapidly (by $\sim 80 \%$ ) after a 24-hour treatment (Fig. 2b). On the fourth day, Mycoplasma concentration was $2.3 \%$ of the original concentration. By the sixth day of treatment, Mycoplasma DNA was no longer detectable (data not shown). Overall, direct qPCR method proved 

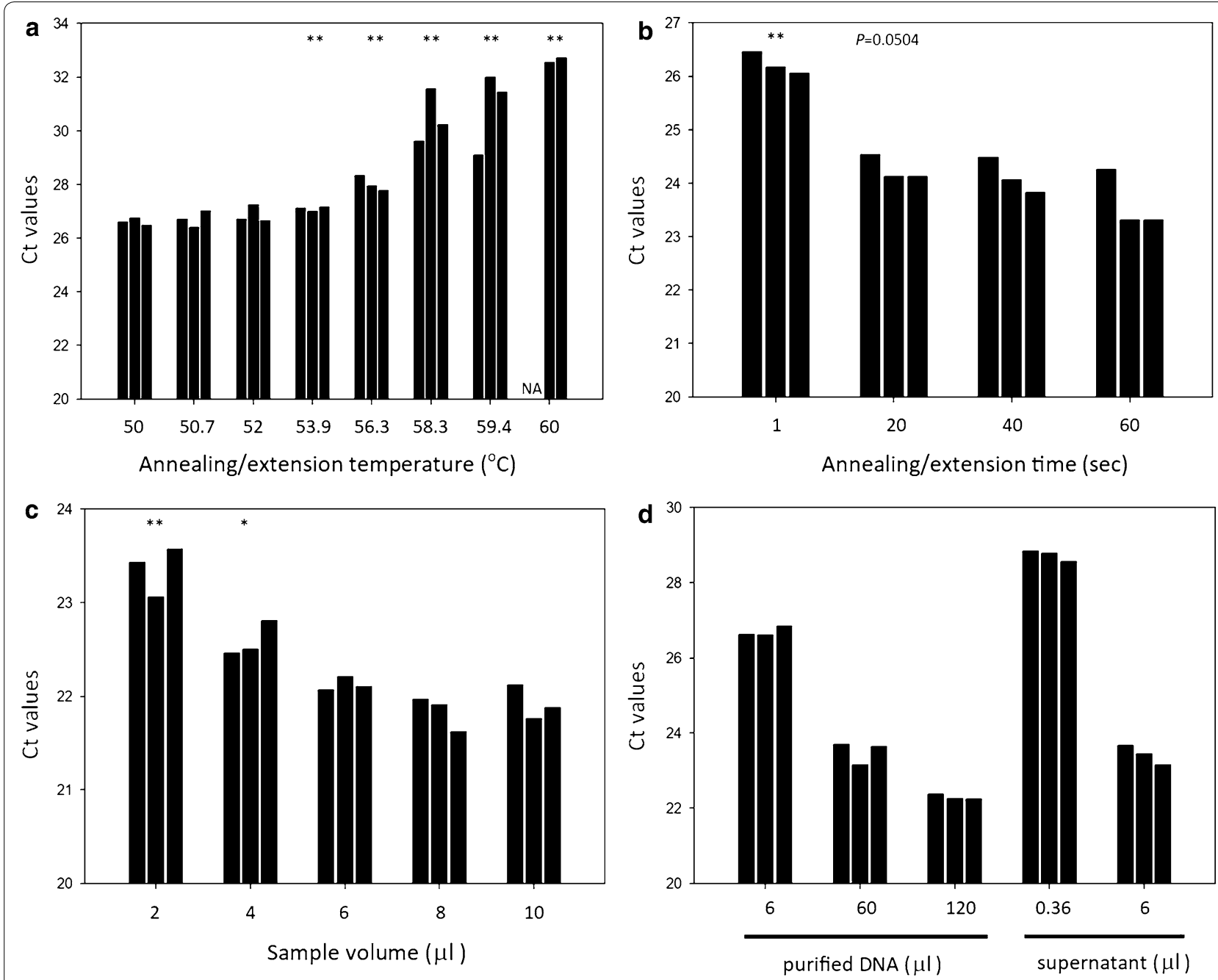

Fig. 1 Optimization of Mycoplasma genus-specific direct qPCR and comparison of its performance with regular qPCR using purified DNA templates. $\mathbf{a}$ Effect of the QPCR annealing/extension temperature on the direct qPCR performance. Student's $t$ test was applied to compare the $C t$ values of samples with various annealing/extension temperatures to those samples with a $50^{\circ} \mathrm{C}$ annealing/extension temperature $(n=3)$. $\mathbf{b}$ Effect of the annealing/extension time on direct qPCR performance. Student's t-test was applied to compare the Ct values of the samples with various annealing/extension times to those samples with a 60 s annealing/extension time $(n=4)$. c Effect of sample volume on direct qPCR performance. Student's t-test was applied to compare the Ct values of various template volume samples with samples having a $10 \mu l$ template volume $(n=3)$. d Comparison of direct qPCR performance with regular qPCR using a purified DNA template $(n=3)$. The DNA was purified from a 6,60 and $120 \mu \mathrm{l}$ cell culture supernatant via the QIAamp protocol and eluted in a $100 \mu$ l elution buffer. $6 \mu$ l of eluted DNA was used in the qPCR procedure. As a comparison, $6 \mu \mathrm{l}$ of the cell culture supernatant was used in direct qPCR. NA: no amplification was detected. ${ }^{*} P<0.05,{ }^{*} P<0.01$

to be a quick and effective method for monitoring the decrease in Mycoplasma DNA during the elimination process.

\section{Discussion}

While various methods exist for the detection of $\mathrm{Myco}$ plasma contamination $[13,14]$, probably the most frequently used ones are biochemical detection of $\mathrm{Myco}$ plasma metabolism and PCR-based detection of Mycoplasma DNA. Though the biochemical detection of mycoplasma ATP generation (Mycoalert (Lonza, Basel, Switzerland)) is a quick protocol, it has certain disadvantages that should be mentioned, including requiring that reagents be reconstituted and brought to $22{ }^{\circ} \mathrm{C}$ before each measurement and requiring a luminometer for ATP detection. Aspecificity due to ATP generated by other cells may lead to a high background and eventually false negative measurements. The Ureaplasma species which are also a common contaminant in a cell culture [15] cannot be detected by Mycoalert as their own ATP 

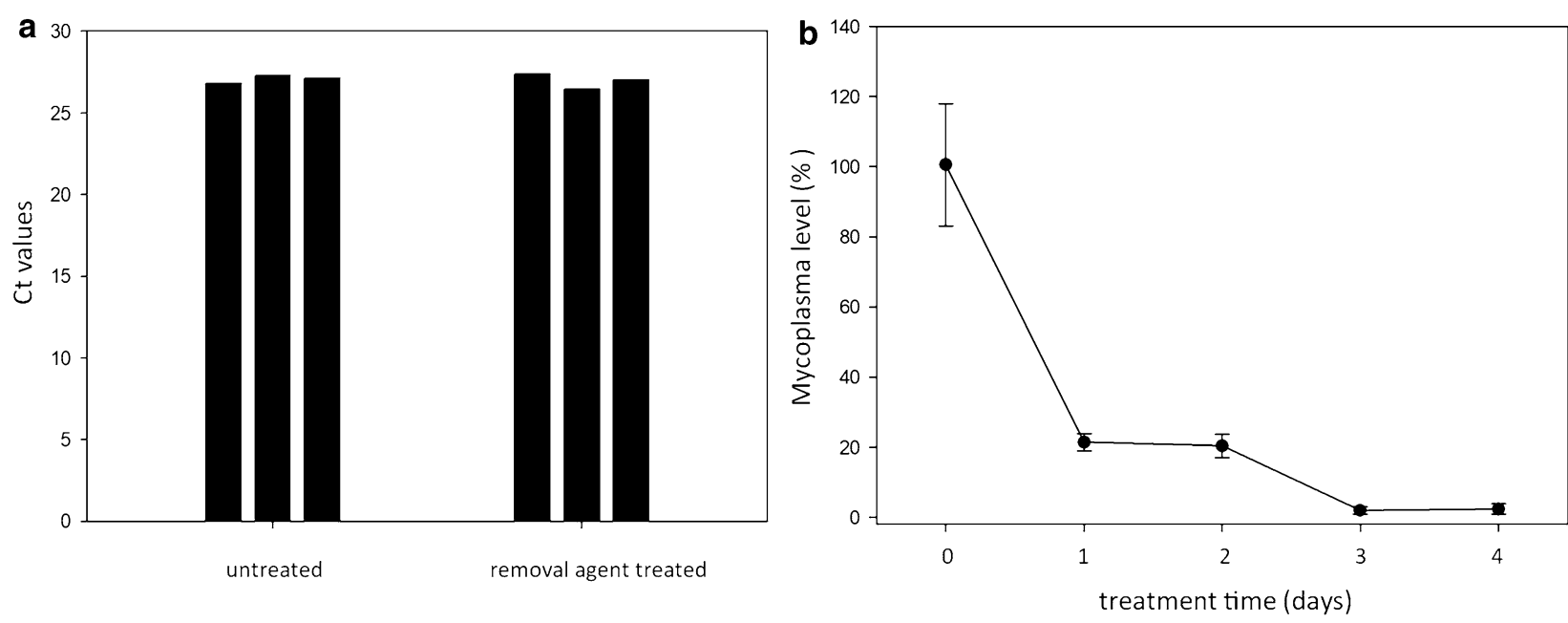

Fig. 2 Monitoring Mycoplasma elimination by direct qPCR. Mycoplasma contaminated U937 cells were treated with Bio-Rad Mycoplasma Removal Agent at $0.5 \mu \mathrm{g} / \mathrm{ml}$ concentration. a A comparison of qPCR Ct values in the absence and presence of Mycoplasma Removal Agent in the medium of contaminated U937 cells. Student's t-test was applied to compare the Ct values of removal agent containing samples with those of removal agent free samples $(n=3)$. $\mathbf{b}$ The first 4 days of treatment monitored by direct $\mathrm{qPCR}$ is shown $(\mathrm{n}=4$ at each time point). The Mycoplasma genome concentration on day 0 was defined as $100 \%$

production relies on the hydrolysis of urea [16]. Finally, the sensitivity of biochemical detection has been shown to be lower than that for PCR or qPCR methods $[17,18]$.

There are a variety of kits on offer based on regular PCR, followed by gel electrophoresis. The major advantage of these kits is the wide availability of regular PCR and electrophoresis equipment. However, decreased specificity compared to probe-based qPCR, the additional electrophoresis step, and the inability to quantitatively monitor the decrease in Mycoplasma genome concentration during treatment are clear drawbacks. Intercalation-based (e.g. SYBR Green) qPCR kits such as MycoSEQ Mycoplasma Detection Assay (Thermo Fisher, Waltham, MA, USA) eliminate the electrophoresis step and provide quantitative information about Mycoplasma genome concentration. The disadvantages of intercalation-based qPCR kits compared to probe-based kits are a lower specificity, lack of internal control and the potential effect of cell culture composition, ionic composition and ionic strength to change the melting temperature of the $\mathrm{qPCR}$ product [19-21]. Since this melting temperature is the basis for evaluating specificity in intercalation based qPCRs, changing it can be problematic. Probebased qPCRs such as PhoenixDx (Procomcure Biotech, Thalgau, Austria), Microsart RESEARCH Mycoplasma (Sartorius, Goettingen, Germany) and qPCR Detection Kit (XpressBio, Frederick, MD, USA) avoid these problems and due the additional requirement of the binding of the probe sequence, these kits provide a higher specificity than regular PCRs and intercalation-based qPCRs.
Noting the advantages of probe-based qPCRs, we optimized the Procomcure PhoenixDx kit to perform a direct qPCR with a Mycoplasma infected U937 cell culture. Our results indicates that the optimal temperature was the same as that in the original protocol, so the primer + probe binding was not affected by the presence of the direct template. The fact that the optimal template volume was $6 \mu \mathrm{l}$ (30\% of the total qPCR volume) meant that the direct sample did not have a significant inhibitory effect on the qPCR. A major optimization step that we performed was decreasing the annealing/extension time from $60 \mathrm{~s}$ to $20 \mathrm{~s}$, thus saving $40 \mathrm{~s}$ in each cycle. Interestingly, this decrease led to only a minor decrease in the sensitivity ( $\sim 0.6 \mathrm{Ct}$ level increase). In addition, decreasing the number of cycles from 50 to 40 , reduced the total qPCR time required to $65 \mathrm{~min}$. When we used the optimized $\mathrm{qPCR}$ protocol with direct and purified cell culture templates, we found that Ct levels of a $6 \mu \mathrm{l}$ direct template was almost identical to that of purified DNA from a $60 \mu \mathrm{l}$ cell culture. The reason for this is mainly due to a dilution of the original DNA content during the elution step at the end of DNA purification. Overall in our case, direct qPCR sensitivity was higher than qPCR with a purified template, with a saving in the cost/time of DNA purification. We monitored the elimination of Mycoplasma contamination from the U937 cell culture using the optimized direct qPCR protocol. One of the concerns using pathogen DNA detection is that the non-viable pathogen's DNA can also be detected and lead to a false positive signal. In our case however, the 
Mycoplasma DNA content dropped to $\sim 20 \%$ of the original concentration after 1 day of treatment, and though days 1 and 2 contained a similar level of DNA, this decrease continued on day 3 . In summary, with direct qPCR we were able to monitor the elimination of $\mathrm{Myco-}$ plasma over the treatment period.

In conclusion, we optimized a probe-based qPCR to detect Mycoplasma contamination in a user-friendly manner. This direct qPCR method does not require a purification step, maintains sensitivity and offers a shorter 65 min protocol.

\section{Limitations}

While we did not observe a major qPCR inhibitory effect of U937 cell culture, it cannot be ruled out that components of other cell cultures may have an inhibitory effect. Most probe based qPCR kits, including the kit used here, contain an internal control (e.g. HEX-labelled probe), therefore the detection of qPCR inhibition (no FAM, no HEX signals) is straightforward. In the case of qPCR inhibition, dilution of the direct sample may be a solution for decreasing/eliminating qPCR inhibition.

\section{Abbreviations}

qPCR: quantitative PCR; Ct: cycle threshold.

\section{Acknowledgements}

Not applicable.

\begin{abstract}
Authors' contributions
ZB: performed optimization experiments, was involved in preparing the manuscript and figures. FS: study design, performed optimization experiments, was involved in preparing the manuscript. SB: performed optimization experiments, was involved in preparing the manuscript. KÖ: involved in the study design, and preparing the manuscript. All authors read and approved the final manuscript.
\end{abstract}

\section{Funding}

This project, design of the study and the analysis was supported by the University of Szeged, Faculty of Medicine (Grant Number: Hetenyi-5S 575 A202). The publication of the article was supported by the University of Szeged Open Access Fund (MPL-USZ-BMCSO-0117).

\section{Availability of data and materials}

Not applicable.

\section{Ethics approval and consent to participate}

Not applicable.

\section{Consent for publication}

Not applicable.

\section{Competing interests}

The authors declare the following competing interests: SB and KÖ are employees of Procomcure Biotech $\mathrm{GmbH}$, the manufacturer of the PhoenixDx ${ }^{\circledR}$ Mycoplasma Mix.

\section{Author details}

${ }^{1}$ Department of Medical Microbiology and Immunobiology, Faculty of Medicine, University of Szeged, Dóm sq. 10., Szeged 6720, Hungary. ${ }^{2}$ Procomcure Biotech GmbH, Breitwies 1, 5303 Thalgau, Austria.
Received: 19 September 2019 Accepted: 24 October 2019

Published online: 01 November 2019

\section{References}

1. Drexler HG, Uphoff CC. Mycoplasma contamination of cell cultures: incidence, sources, effects, detection, elimination, prevention. Cytotechnology. 2002;39:75-90.

2. Feng N, Huang X, Jia Y. Mycoplasma contamination affects cell characteristics and decreases the sensitivity of BV2 microglia to LPS stimulation. Cytotechnology. 2019;71:623-34.

3. Hoff FW, Hu CW, Qutub AA, Qiu Y, Graver E, Hoang G, et al. Mycoplasma contamination of leukemic cell lines alters protein expression determined by reverse phase protein arrays. Cytotechnology. 2018;70:1529-35.

4. Benedetti F, Davinelli S, Krishnan S, Gallo RC, Scapagnini G, Zella D, et al. Sulfur compounds block MCP-1 production by Mycoplasma fermentans-infected macrophages through NF-kB inhibition. J Transl Med. 2014:12:145.

5. Yang J, Hooper WC, Phillips DJ, Talkington DF. Interleukin-1 beta responses to Mycoplasma pneumoniae infection are cell-type specific Microb Pathog. 2003;34:17-25.

6. Eszik I, Lantos I, Önder K, Somogyvári F, Burián K, Endrész V, et al. High dynamic range detection of Chlamydia trachomatis growth by direct quantitative PCR of the infected cells. J Microbiol Methods. 2016;120:15-22.

7. Bogdanov A, Janovák L, Lantos I, Endrész V, Sebők D, Szabó T, et al. Nonactivated titanium-dioxide nanoparticles promote the growth of Chlamydia trachomatis and decrease the antimicrobial activity of silver nanoparticles. J Appl Microbiol. 2017:123:1335-45.

8. Lantos I, Virok DP, Mosolygó T, Rázga Z, Burián K, Endrész V. Growth characteristics of Chlamydia trachomatis in human intestinal epithelial $\mathrm{CaCO}_{2}$ cells. Pathog Dis. 2018;76:fty024.

9. Párducz L, Eszik I, Wagner G, Burián K, Endrész V, Virok DP. Impact of antiseptics on Chlamydia trachomatis growth. Lett Appl Microbiol. 2016;63:260-7

10. Raffai T, Burián K, Janovák L, Bogdanov A, Hegemann JH, Endrész $V$, et al. Vaginal gel component hydroxyethyl cellulose significantly enhances the infectivity of Chlamydia trachomatis serovars D and E. Antimicrob Agents Chemother. 2019;63:e02034-3018.

11. Virók DP, Eszik I, Mosolygó T, Önder K, Endrész V, Burián K. A direct quantitative PCR-based measurement of herpes simplex virus susceptibility to antiviral drugs and neutralizing antibodies. J Virol Methods. 2017;242:46-52.

12. Yuan JS, Reed A, Chen F, Stewart CN. Statistical analysis of real-time PCR data. BMC Bioinform. 2006;7:85.

13. Wehbe K, Vezzalini M, Cinque G. Detection of mycoplasma in contaminated mammalian cell culture using FTIR microspectroscopy. Anal Bioanal Chem. 2018:410:3003-16.

14. Soheily Z, Soleimani M, Majidzadeh-Ardebili K. Detection of mycoplasma contamination of cell culture by a loop-mediated isothermal amplification method. Cell J. 2019;21:43-8.

15. Kotani H, McGarrity GJ. Ureaplasma infection of cell cultures. Infect Immun. 1986:52:437-44.

16. Volokhov DV, Graham LJ, Brorson KA, Chizhikov VE. Mycoplasma testing of cell substrates and biologics: review of alternative non-microbiological techniques. Mol Cell Probes. 2011;25:69-77.

17. Molla Kazemiha $V$, Amanzadeh A, Memarnejadian A, Azari S, Shokrgozar MA, Mahdian R, et al. Sensitivity of biochemical test in comparison with other methods for the detection of mycoplasma contamination in human and animal cell lines stored in the National Cell Bank of Iran. Cytotechnology. 2014;66:861-73.

18. Molla Kazemiha $\vee$, Bonakdar S, Amanzadeh A, Azari S, Memarnejadian A, Shahbazi S, et al. Real-time PCR assay is superior to other methods for the detection of mycoplasma contamination in the cell lines of the National Cell Bank of Iran. Cytotechnology. 2016;68:1063-80.

19. Duguid JG, Bloomfield VA, Benevides JM, Thomas GJ. Raman spectroscopy of DNA-metal complexes II The thermal denaturation of DNA in the presence of $\mathrm{Sr}^{2+}, \mathrm{Ba}^{2+}, \mathrm{Mg}^{2+}, \mathrm{Ca}^{2+}, \mathrm{Mn}^{2+}, \mathrm{Co}^{2+}, \mathrm{Ni}^{2+}$, and $\mathrm{Cd}^{2+}$. Biophys J. 1995;69:2623-41. 
20. Wang J, Pan X, Liang X. Assessment for melting temperature measurement of nucleic acid by HRM. J Anal Methods Chem. 2016;2016:5318935.

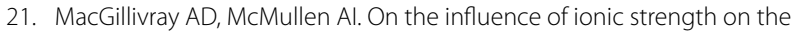
melting temperature of DNA. J Theor Biol. 1966;12:260-5.

\section{Publisher's Note}

Springer Nature remains neutral with regard to jurisdictional claims in published maps and institutional affiliations.
Ready to submit your research? Choose BMC and benefit from:

- fast, convenient online submission

- thorough peer review by experienced researchers in your field

- rapid publication on acceptance

- support for research data, including large and complex data types

- gold Open Access which fosters wider collaboration and increased citations

- maximum visibility for your research: over $100 \mathrm{M}$ website views per year

At BMC, research is always in progress.

Learn more biomedcentral.com/submissions 